\title{
From city streets to suburban woodlands: the urban planning debate on children's needs, and childhood reminiscences, of 1940s-1970s Helsinki
}

\author{
Veera Moll ${ }^{\star 1}$ and Hanna Kuusi ${ }^{2}$ \\ ${ }^{1}$ Department of Built Environment, PO Box 14100, FI-00076 AALTO, Finland \\ ${ }^{2}$ Social Science History, PO Box 54, FI-00014 University of Helsinki, Finland \\ ${ }^{*}$ Corresponding author. Email: veera.moll@aalto.fi
}

\begin{abstract}
Finnish children today enjoy a relatively high level of independent mobility. This article discusses how different urban planning professionals defined children's needs in a postWorld War II Helsinki that was undergoing rapid urbanization, and how these discourses relate to childhood memories of the time. The emphasis on family by the planning professionals led to major changes in the city structure, including developed play areas, safer streets and shorter distances to schools. This study suggests that a dominant understanding of the importance of outdoor activities has contributed to the relatively stable level of independent mobility of the children in Helsinki.
\end{abstract}

\section{Introduction}

It was not uncommon in the 1970s for a six-year-old girl living in the capital city of Helsinki to take a tram by herself to her ballet class. This would not happen today. The decrease in children's independent mobility and access to their neighbourhoods is an international phenomenon. ${ }^{1}$

\footnotetext{
${ }^{1}$ According to urban geographer Lia Karsten, public space in Amsterdam was transformed from a children's space into an adult space between the 1950s and the 2000s, and children spend more time indoors than before. However, the differences among children in their daily use of space have changed. Studies undertaken in England, in New York, USA and in New Zealand have also noted a decrease in children's independent mobility and access to their neighbourhoods. See, e.g., L. Karsten, 'It all used to be better? Different generations in conceptions and opportunities on continuity and change in urban children's daily use of space', Children's Geographies, 3 (2005), 275-90; M. Hillman, J. Adams and J. Whitelegg, One False Move. A Study of Children's Independent Mobility (London, 1990); H.E. Woolley and E. Griffin, 'Decreasing experience of home range, outdoor spaces, activities and companions: changes across three generations in Sheffield in north England', Children's Geographies, 13 (2015), 677-91; S. Gaster, 'Urban children's access to their neighbourhood. Changes over three generations', Environment and Behaviour, 23 (1991), 70-85; J. Bhosale, 'Understanding children's independent mobility', Auckland University of Technology Ph.D. thesis, 2015.

(C) The Author(s) 2019. This is an Open Access article, distributed under the terms of the Creative Commons Attribution licence (http://creativecommons.org/licenses/by/4.0/), which permits unrestricted re-use, distribution, and reproduction in any medium, provided the original work is properly cited.
} 
However, when compared with other countries, Finnish children still move around relatively independently. According to the results of a large international study, children in Finland are, for example, allowed to walk and cycle in the nearby surroundings, cross main roads by themselves and go out after dark alone at an earlier age than others. In fact, in terms of children's independent mobility, Finland was the highest ranked country followed by Germany, Norway, Sweden, Japan and Denmark. ${ }^{2}$

Children's decreasing freedom to move about and roam without adult supervision is one of the growing challenges in urban children's lives today. Lack of independent mobility has been connected with too little physical activity as well as obesity. ${ }^{3}$ Lack of independence also limits children's opportunities to learn about their surroundings. As Julie Bhosale puts it, 'Children who experience greater autonomy in their neighbourhood are also more likely to take risks, which is necessary to develop resilience and self-confidence in preparation for the adult world. ${ }^{4}$ Hindering or enabling independent mobility is closely related to questions of equality, of who has the right and potential to move within a city.

To understand the background of Finnish children's exceptional yet diminishing independent mobility, we need to look at the past. In our research, we aimed to explore how from the perspective of children the urban environment has developed and changed, both in terms of concern about children and with regard to the experiences of children themselves. Previously, only a few studies have focused on the history of urban children in Finland. With some exceptions, deviant street boys have aroused the interest of historians and some ethnological studies have been done about childhood in the city. An important work on children's environmental urban history based on reminiscence sources was introduced by Simo Laakkonen. According to him, the city children of the past seem to be almost 'academic orphans', in other words a largely unresearched area. ${ }^{5}$ The same lack of historical studies has been noted by Lia Karsten and by Colin G. Pooley, Jean Turnbull and Mags Adams. ${ }^{6}$

To shed light on the role given to children in Finnish urban planning and development during the post-war era, the aim of this article was to explore how ideal city spaces for children were envisioned in the public discourses by various professionals from the 1940s to the 1970s. Related to this, we further reflect on how the discussions and development of Finnish urban environments have contributed to the culture of children's independent mobility, if at all.

\footnotetext{
${ }^{2}$ The research conducted by the Policy Studies Institute in 2015 included 16 countries. See B. Shaw, M. Bicket, B. Elliott, B. Fagan-Watson, E. Mocca and M. Hillman, Children's Independent Mobility. An International Comparison and Recommendations for Action (London, 2015), 20, vi.

${ }^{3}$ Shaw et al., Children's Independent Mobility, 4.

${ }^{4}$ Bhosale, 'Understanding children's independent mobility', 17.

${ }^{5}$ S. Laakkonen, 'Asphalt kids and the matrix city: reminiscences of children's urban environmental history', Urban History, 38 (2011), 303.

${ }^{6}$ Karsten, 'It all used to be better?', 276; C. Pooley, J. Turnbull and M. Adams, 'Kids in town: the changing action space and visibility of young people in urban areas', in D. Siegfried and A. Schildt (eds.), European Cities, Youth and the Public Sphere in the Twentieth Century (London, 2005), 90. Their studies are also central contributions to the field.
} 
Public discussion on urban planning was active after World War II, families in particular being at the centre of the debate. Focusing on forums of public discussion, such as magazines for professionals and wider audiences, pamphlets and documentary films, we studied how the needs of children and the ideal surroundings for them were perceived and expressed, and how the arguments changed over time. To broaden the perspective and to create a context for the public discourses, we included oral history by children from that time.

\section{Background}

The population of Helsinki increased significantly after World War II (1939-45) with an increase of 82 per cent in 30 years. ${ }^{7}$ Evacuees from the ceded Karelia region and migrants from the countryside poured into the capital city and the baby boom further increased the number of inhabitants. Moreover, the area of Helsinki expanded geographically in 1946.

In the 1950s, before the city of Helsinki effectively responded to the housing shortage, homes were generally overcrowded. Living was cramped in all social classes. In the late 1940 s, the city authorities had even ordered that spare rooms in the bigger apartments should have compulsory lodgers. This coincided with a rapid increase in the birth rate, with the Finnish post-war baby boomers being born between 1945 and 1950. Due to overcrowding and small apartments, urban children spent plenty of time outdoors with other children. In line with studies carried out in Amsterdam, Finnish reminiscences confirm the dominance of outdoor play in 1950s Helsinki. ${ }^{8}$ As Lisa Karsten put it, public space was defined as the 'natural' place for children, while home space was primarily defined as an adult space. ${ }^{9}$ This was the case particularly with working-class children, who rarely had an opportunity to play with their friends at home. ${ }^{10}$

The effort made for children to get as much fresh air, light and sunshine outdoors as possible was a major part of the hygiene movement in the early decades of the twentieth century, both in Finland and elsewhere. Tuberculosis was common, was spread in cramped living quarters, and there was no cure. All that could be done was to strengthen one's lungs and body to prevent the disease. Cities coped differently with increasing worries about urban health and the welfare of the young. According to David Pomfret, in inter-war Nottingham in England, young people were provided with clinics, open-air schools and playing fields within the city, whereas in Saint-Etienne in France the youth were offered extrication services. ${ }^{11}$ The custom of sending urban children to the countryside during the summer was also introduced in Finland.

However, not all outdoor spaces were recommended. Street life was often morally condemned; only vagrants and youth gangs wandered along city streets. From

\footnotetext{
${ }^{7}$ Statistical Yearbook of Helsinki 2012 (Helsinki, 2012), 27, www.hel.fi/hel2/tietokeskus/julkaisut/pdf/ 13_01_03_Tilastollinen_vuosikirja_2012.pdf, accessed 31 Jan. 2019.

${ }^{8}$ Laakkonen, 'Asphalt kids and the matrix city', 305-19.

${ }^{9}$ Karsten, 'It all used to be better?', 282.

${ }^{10} \mathrm{H}$. Paunonen, J. Vuolteenaho and T. Ainiala, 'Industrial urbanization, working-class lads and slang toponyms in early twentieth-century Helsinki', Urban History, 36 (2009), 457.

${ }^{11} \mathrm{D}$. Pomfret, "The city of evil and the great outdoors: the modern health movement and the urban young, 1918-40', Urban History, 28 (2001), 426-7.
} 
early on, the cities had been active in constructing legitimate public spaces for outdoor recreation, including parks and sport facilities for both children and adults. However, this was not enough for the post-war social reformists. They were urging that there should be proper facilities and better urban environment for families, i.e. garden cities.

The ideas were realized rather rapidly during post-World War II reconstruction. The structure of urban Helsinki began to change profoundly as new ideal suburban areas were built. In Kirsi Saarikangas' words, 'Finland was urbanized and modernized through becoming suburbanized.' ${ }^{\prime 2}$ The new suburbs offered not only bigger homes with proper heating and sanitary facilities for a greater number of people, but also outdoor green spaces for residents. Those close to nature suburbs were considered particularly ideal for families with children.

The contrast with earlier urban planning was pronounced. The new suburbs created during the 1950s and early 1960s featured either long four-floor apartment buildings or separate high-rises loosely scattered among the natural formations of the landscape. The street design was branch-like and there was plenty of space between the buildings, in strong contrast to urban city blocks. The new housing areas were praised by contemporary media: 'there was sun, freedom and fresh air for the new generation to grow up as brave and high-spirited youngsters.' ${ }^{13}$

Due to the massive suburban construction projects, overcrowding in the central city was alleviated even though the capital continued to attract migrants from the countryside. From 1962 to 1987, the population of central Helsinki dropped 39 per cent, whereas that of suburban Helsinki grew almost 66 per cent, from 195,000 to $324,000 .{ }^{14}$ New city streets and an expanding transportation system altered the urban landscape of Helsinki. From 1950 to 1980, the number of registered cars rose from 6,035 to $114,796 .{ }^{15}$ Concurrently, the number of car accidents increased.

\section{Professional discourses and children's experiences}

In a well-known pamphlet, Koti vaiko kasarmi lapsillemme (Home or barracks for our children) from 1946, Heikki von Hertzen demanded better housing quality, and greener and more spacious living environments for citizens and especially for families. Von Hertzen was the executive manager of Väestöliitto (the Finnish Population and Family Welfare Federation), which later published the journals Asuntopolitiikka (Housing Policy), 1950-66, and ValtakunnansuunnitteluAsuntopolitiikka (National Planning), 1967-72, delivered to politicians and professionals dealing with housing issues. The authors of these magazines were respected architects such as Alvar Aalto and planner and architect Otto-Iivari Meurman, politicians such as Kaarlo af Heurlin and the social reformist and garden city advocate, Heikki von Hertzen. Von Hertzen and Meurman were active in demanding

\footnotetext{
${ }^{12} \mathrm{~K}$. Saarikangas, 'Sandboxes and heavenly dwellings. Gender, agency, and modernity in lived suburban spaces in the Helsinki metropolitan area in the 1950s and 1960s', Home Cultures, 11 (2014), 43.

${ }^{13}$ Oy Filmiseppo, Helsinki kasvaa (Helsinki grows), 13 min., documentary film (1957).

${ }^{14} \mathrm{O}$. Turpeinen, 'Väestö', in T. Herranen, K. Hoffman and O. Turpeinen, Helsingin historia vuodesta 1945. Osa 1: Väestö, kaupunkisuunnittelu, asuminen ja elinkeinot (Helsinki, 1997), 21.

${ }^{15}$ www.hel.fi/static/tieke/digitoidut_asiakirjat/helsingin_kaupungin_tilastolliset_vuosikirjat/index.html, accessed 31 Jan. 2019.
} 
family-oriented urban planning and referred to visionary reformists such as American sociologist Lewis Mumford. They were also influenced by earlier social reformists. For example, Ebenezer Howard, according to Robert Fishman, had believed that 'radical reconstruction of the cities would solve not only the urban crisis of their time but also the social crisis as well'. ${ }^{16}$ Von Hertzen and Meurman believed too that family values could better flourish in proper housing conditions instead of the dark and cramped slums of the old city. This was the general consensus in all the source materials examined up until the 1960s, when newly built suburbs started being increasingly criticized by a new generation of architects.

In order to include the views of another type of expertise, the magazine Lapsi ja nuoriso (Child and Youth), 1955-72, was also incorporated in the source material for this study. It was published by the Central Union for Child Welfare, aimed at audiences working with children and young people and gave voice to various professionals: psychologists, social workers, teachers, day care workers as well as playground leaders and other experts.

The concern for children's spatial needs both indoors and out was also strongly present in three publications by a Finnish NGO, the Mannerheim League for Child Welfare. ${ }^{17}$ The authors, architect Tapio Periäinen and child advocate Seppo Sauro, did not make an argument for the reconstruction of entire cities but pointed out that children's diverse needs, such as play spaces and protection, had to be taken into account in urban planning.

In addition, the corresponding garden city ideals were discussed widely in the popular media. Even though primarily an interior design magazine, Kaunis koti (Beautiful Home), 1948-71, which merged with Avotakka (Open Hearth) in 1971, debated issues of housing environment, but often from the perspective of individual families. Even wider audiences were reached through documentary films, either those produced for tax reduction purposes shown before feature films in cinemas or the later ones produced for television. We selected five documentary films for analysis. Two short documentary films presented reports on children's free time from an adult perspective. ${ }^{18}$ Additionally, two longer 20-minute documentary films were directed by a promising young filmmaker Risto Jarva. The documentary film in particular, which described the possibilities of the new urban life in a positive tone, received a lot of attention in Finland. The last one selected was a three-minute clip from a 1976 television documentary forcefully criticizing the dull life of children in a Finnish suburb and using strong words and images. ${ }^{19}$

\footnotetext{
${ }^{16}$ R. Fishman, 'Urban utopias: Ebenezer Howard and Le Corbusier', in S. Campbell and S. Fainstein (eds.), Readings in Planning Theory (Cambridge, 1996), 20.

${ }^{17}$ T. Periäinen, A4 Asumispoliittinen tavoiteohjelma (Helsinki, 1971); T. Periäinen, A4 Asumispoliittinen tavoiteohjelman tiivistelmä (Helsinki, 1971); S. Sauro, A1 Lapsiraportti. Mitä lapsi tarvitsee asumisessa? (Helsinki, 1977).

${ }^{18}$ Työtä ja lomailua (Work and vacation) by Lii-Filmi, 1950s, 6 min.; Harrastuksia (Hobbies) by YLE (The Finnish Broadcasting Company), 1958, 7 min. Both can be found in the YLE archives.

${ }^{19}$ Kaupungissa on tulevaisuus (Town is our future), 22 min., directed by Risto Jarva, Filminor Oy, 1967, and Maaseudun tulevaisuus? (The future of the countryside?), 25 min., directed by Risto Jarva, Filminor Oy, 1970; Lapset lähiössä (Children in the suburbs), 2 min. 51 sec., YLE, 1976.
} 
The published material gathered for analysis was available for both professional and wider audiences. Some authors wrote with the agenda of raising money for construction projects, thus the rhetoric used was rather forceful. Accordingly, the focus of the research has been on the active role of the written and visual material in constructing social reality. The methodology used could be called historical discourse analysis, where the emphasis is on the historical context of the categorizations and the logic of the argumentation. The analysis was systematic, identifying typical structures of signification in the statements of authors holding expert positions. The texts were analysed as social practice, with a coding frame of problem, reason, solution and an ideal state of matters, and possible threats. Special attention with thematic coding was paid to arguments and descriptions of the old and densely populated centre of Helsinki, as well as to claims about the garden city, suburbs and children's needs in the city in general.

The view of the social reformists, urban planners and other experts would be rather one-sided if the experiences of the children themselves were not considered here. For that purpose, an oral history perspective was also included. A similar approach has been used by environmental historian Simo Laakkonen, whose research project collected written reminiscences from an earlier period, mainly from the 1920s to the 1950s. The responses depict a rather active and nature-oriented picture of children's mobility in Helsinki. Even the pre-suburban capital offered plenty of nature and open spaces, and children wandered freely, went swimming, cycling and picked berries and mushrooms. ${ }^{20}$ This was very different from what one would conclude from the writings of the urban planning experts at that time.

Reminiscences related to the urban surroundings in the city of Helsinki have also been collected by different city district organizations. Here, we made use of reminiscences gathered in Helsinki's central Töölö as well as suburban Siilitie and Kontula. ${ }^{21}$ In addition, the major newspaper Helsingin Sanomat collected experiences of living in 38 suburbs of the Helsinki metropolitan area in the 1990s, which provided plentiful memories from childhood and adolescent years. ${ }^{22}$ Despite the different purposes and occasions of these collections of reminiscences in the late 1990 s and early 2000 s, either for research, community history or journalism, the contents are very similar. They are all written reminiscences, and represent answers to open calls by the organizers. The tradition of collecting personal reminiscences is strong in Finland, and the idea of writing one's own history is one that has gained considerable popularity. Of course, this kind of oral history material naturally has its own characteristics and limitations.

Written reminiscences offer an insight into experiences, emotional positions and attitudes rather than proof of events in the past. However, for the purposes of exploring how children interacted with their environment during these times, the reminiscences are very fruitful. As Pia Olsson has noted, children tend to value

\footnotetext{
${ }^{20}$ Laakkonen, 'Asphalt kids and the matrix city'.

${ }^{21}$ J. Kesänen, Siilitien tarinat. Kirjoituksia kaupunkielämästä (Helsinki, 2002); J. Kokkonen, Kontula: elämää lähiössä (Helsinki, 2002); 'The stories of Siilitie' with 51 responses, were collected in co-operation with the Finnish Literature Society.

${ }^{22}$ R. Astikainen, R. Heiskanen and R. Kaikkonen, Elämää lähiössä (Helsinki, 1997).
} 
their environment for the framework it provides for different activities, not for its aesthetic qualities. ${ }^{23}$ Of course, childhood memories are afterimages, filtered by adult views and later life courses. They are full of nostalgia, and the negative memories of unfortunate incidents, fear and anxiety are most frequently reported when trials and tribulations are overcome. Consequently, the contemporary professional discourses and the reminiscences are not juxtaposed as such, but are triangulated for a multiperspective analysis.

\section{The dangers of downtown streets}

How was the ideal urban space for children projected in the public discourses by social reformists and other planners after World War II? First and foremost, a city environment was considered too dangerous for children. This message is expressed frequently in the source material, even though the number of cars was quite modest in the early post-war years. In 1950, there were approximately 15 automobiles per 1,000 inhabitants; 30 years later, the number was 291 . The increase within what was roughly the same spatial area was very notable, and led to the increase of accidents. On average, three people died in Finland every day in traffic accidents in the 1960s. The rate began to fall only in the early 1970s due to improved roads, safer vehicles, tighter road legislation, new and safer infrastructures and education as well as more effective first responders and medical treatment. ${ }^{24}$

Childhood reminiscences, professional discourses and traffic accident statistics all confirm the significant change that automobiles brought to the city and its children. In Amsterdam, too, the loss of children's outdoor space has been mainly explained as a result of the space lost to increasing traffic especially between 1950 and $1975 .^{25}$ This was an important agenda for contemporaries in Finland as well. One of the main arguments for the new kind of residential areas was said to be the dangers of automobiles in the city centre. As increasing traffic was seen as inevitable and uncontrollable, children were to be relocated from the city centre to safer areas, i.e. the garden cities and suburbs.

However, the benefits of having a large variety of children's play spaces and the importance of free street play, often depicted in childhood reminiscences, was ignored in Finnish discussions, whereas in England, for instance, despite some criticism, special play streets were introduced as early as the 1930s. According to Krista Cowman, play streets closed to traffic for the most of the day became popular in post-war England and were actively defended by working-class mothers. ${ }^{26}$ Campaigns for play streets in working-class districts were fuelled by growing criticism of cars 'which they [campaign leading women] considered illegitimate

\footnotetext{
${ }^{23} \mathrm{P}$. Olsson, 'Modes of living and local identity: formations in two districts in Helsinki', in P. Korkiakangas, P. Olsson and A.-M. Åström (eds.), Memories of my Town: The Identities of Town Dwellers and their Places in Three Finnish Towns (Helsinki, 2004), 93.

${ }^{24}$ Statistical Yearbook of Finland 1975 (Helsinki, 1976). For traffic accidents, see: http://pxnet2.stat.fi/ PXWeb/pxweb/en/StatFin/StatFin_lii_ton/statfin_ton_pxt_010_fi.px/, accessed 23 Aug. 2019.

${ }^{25}$ Karsten, 'It all used to be better?', 276-7.

${ }^{26} \mathrm{~K}$. Cowman, 'Play streets: women, children and the problem of urban traffic, 1930-1970', Social History, 42 (2017), 253.
} 
travellers through their streets rather than an accepted part of their life'. ${ }^{27}$ The solution offered by social reformists to the traffic problem in Finland was the total separation of motorized traffic from pedestrians. 'Children have to get from home to school without crossing one road ${ }^{28}$ was written in Asuntopolitiikka in 1950. This separation was not carried out in downtown Helsinki but it was in the new suburbs. In the Finnish discourses, the need for separate playgrounds, sports fields and other child-specific spaces was also emphasized.

Not only the traffic but also the 'social dangers' of the city were central justifications for relocating families from the city centre to the suburbs of Helsinki. Social dangers were rarely defined clearly by contemporaries; however, they were essentially considered to be related to crime and alcoholism. ${ }^{29}$ Improving housing conditions, substituting the dark and cramped habitation of the downtown with new dwellings in the suburbs was believed to have an instantaneous positive effect on families. The pursuit of shaping the urban environment and especially children's use of space was a tool for shaping the whole nation.

Architect and planner Otto-Iivari Meurman had a solution to the poor living conditions of urban children. In his influential textbook Asemakaavaoppi (Town planning), widely used in the training of the new urban planners, Meurman expressed in detail the demands for a child-friendly scale in urban planning and refined the ideas of the garden city movement. Although complete garden cities were never actualized in Finland, according to Ulla Salmela 'the garden city idea was consciously adopted as a manifold whole' by Finnish planners. ${ }^{30}$

In Meurman's view, a 'stroller-distance' was the ideal scale for a residential unit. Homes were expected to be close enough to shops, children's day care centres, playgrounds and other services. The neighbourhood unit was supposed to offer services such as a school and a small shopping centre. The standard distance for a child's walk to school was short, ideally 600-800 metres. The neighbourhood would ideally also include services such as sports fields and other recreational facilities. ${ }^{31}$ Not all the suburbs wound up with such good services, although similarly designed services can be found in many of the Finnish suburbs.

It can be argued that the mission to create safer environments for children was fulfilled. Traffic accidents decreased despite the fact that the volume of traffic kept growing. ${ }^{32}$ It can even be argued that the new suburban environments enabled the continuation of children's independent mobility - the separation of traffic and pedestrians and the walkability of the suburbs made it possible for children to move about without constant adult supervision.

However, city planning also ended up isolating families with children in their own suburban neighbourhoods by choosing not to develop downtown Helsinki

\footnotetext{
${ }^{27}$ Ibid., 246.

${ }^{28}$ Asuntopolitiikka, 2 (1950).

${ }^{29} \mathrm{H}$. von Herzen, Koti vaiko kasarmi lapsillemme: asunnontarvitsijoiden näkökohtia asunto- ja asemakaavakysymyksissä (Porvoo, 1946), 6.

${ }^{30}$ U. Salmela, Urban Space and Social Welfare: Otto-Iivari Meurman as a Planner of Finnish Towns 1914-1937 (Helsinki, 2004), 96.

${ }^{31}$ Asuntopolitiikka, 1 (1950).

${ }^{32}$ M. Syvänen, 'Lasten elintilan kaventuminen', in P. Santalahti, V. Oroza, R. Laakia, M. Koivusalo and E. Hemminki (eds.), Auto, terveys ja ympäristö (Helsinki, 1997), 170.
} 
into a more child-friendly environment and by assigning the suburbs as the only suitable option for family living. The post-war suburbs with their roots in garden city utopias continued to be considered an ideal urban environment for families for decades. Lilius has argued that there is still a lack of understanding about family living in the city centre among city planners and politicians because 'modernist ideals on proper family living still prevail'. ${ }^{33}$

\section{The desire for green}

The journal Asuntopolitiikka for professional audiences continued to repeat the ideas presented in the pamphlet 'Home or barracks for our children' (1946) during the 1950s and 1960s. Also, Kaunis Koti for the public emphasized the need for greener environments for children. New ideal woodland suburbs were actively discussed in other media too. What was not mentioned, however, was that even the old downtown areas of Finnish cities were also relatively green. ${ }^{34}$ Thus, depicting them as sunless stone quarters was an exaggeration.

Helsinki was founded in 1812 as the capital city of the new grand duchy of the Russian empire. Urban green became an important part of construction of the new capital especially from the late nineteenth century. However, for a long period of time, the planned parks were concentrated in better-off areas. ${ }^{35}$ The need for green areas for the lower classes as well had been articulated in the nineteenth and early twentieth centuries, but the proximity of open green spaces in Helsinki may have hindered the motivation to plan new parks in working-class neighbourhoods. ${ }^{36}$

According to historian Katri Lento, from the beginning of the twentieth century until the 1960s, the interest in planning and building green areas was exceptionally high in Helsinki. The private garden community of Kulosaari, the working-class garden projects of Käpylä and rental district of Vallila, public parks, sports fields, the increasing number of children's camps in the countryside and German-style allotment gardens attest to the interest in green planning. ${ }^{37}$ However, in the material analysed for this study, the presence of existing greenery in the city centre was overlooked.

In 1950, architect Alvar Aalto complained that there was only one tree per 17 families when the situation was supposed to be the opposite. ${ }^{38}$ Parks in the city were no longer considered to be sufficient by many post-war commentators; instead, family homes needed to be relocated closer to nature.

All in all, the threats and problems that city life, with its dangerous traffic and poor housing conditions, posed to children in Helsinki were to be avoided by

\footnotetext{
${ }^{33} \mathrm{~J}$. Lilius, 'Is there room for families in the inner city? Life-stage blenders challenging planning', Housing Studies, 29 (2014), 843.

${ }^{34}$ S. Tuomaala, 'Pulpetista pihoille, metsiin ja kaduille', in A. Heikkinen and P. Leino-Kaukiainen, Valistus ja koulunpenkki: Kasvatus ja koulutus Suomessa 1860-luvulta 1960-luvulle (Helsinki, 2011), 361.

${ }^{35} \mathrm{P}$. Clark and M. Hietala, 'Helsinki and green space, 1850-2000: an introduction', in P. Clark (ed.), The European City and Green Space. London, Stockholm, Helsinki and St Petersburg, 1850-2000 (Aldershot, 2006), 175, 177.

${ }^{36}$ Ibid., 177.

${ }^{37} \mathrm{~K}$. Lento, 'The role of nature in the city: green space in Helsinki, 1917-60', in Clark (ed.), The European City, 205.

${ }^{38}$ Asuntopolitiikka, 2 (1950).
} 
relocating residents to the new garden cities, rather than imposing restrictions on city traffic or making the city centre safer, greener or friendlier for children.

Contemporary ideals were given a testing ground with the model suburb of Tapiola, built 10 kilometres west of central Helsinki in the 1950s and 1960s. With housing and shopping centres close to green areas, Tapiola was promoted as a 'Garden City' or 'New Town'. ${ }^{39}$ The realization of Tapiola was an initiative of the Housing Foundation (Asuntosäätiö), founded together with six social organizations. The aim was to build a new housing environment as an alternative to Helsinki's densely populated centre. Children and families were at the core of the planning: numerous facilities for children's hobbies ranging from scouts' huts to youth centres and sports fields were created.

Tapiola was actively promoted and the project received much publicity both in Finland and abroad. The newly fashioned apartments and neighbourhoods were introduced and praised in dozens of articles and the new city was warmly received. However, in the late 1960s, some criticism emerged. The suburb was criticized for its lack of services, for being too family-oriented, and the residents of Tapiola were said to be too homogeneous. Distances to services and children's routes to school were considered too long. Sidewalks were still missing and the bicycle paths and pedestrian crossings were felt to be dangerous. Children were playing in the streets and in parking lots. The goal of a safe urban environment had not yet been achieved, some thought. However, it was noted that Tapiola residents were content with their neighbourhood and the city itself could still be considered an exemplary residential area. ${ }^{40}$

In reply to the critique, the managing director of the Housing Foundation, Heikki von Hertzen, wrote that he was still content with Tapiola. He argued that the expectations for the garden city had been very high, even impossible to fulfil, but that the area was still extraordinary compared to the other suburbs built elsewhere at the time. ${ }^{41}$ However, the uniqueness of the project can be questioned. The principles of functional and green urban planning had led to rather similar results in other contemporary suburbs, although the extent and range of the elements of a 'garden city' varied. Be this as it may, the post-war social reformists had (yet) again accomplished their mission: children were saved from the increasing traffic, and many families had relocated from city centres or the countryside to more spacious homes in the green suburbs.

\section{Designed and undesigned space for physical activities}

In the pursuit of more beneficial neighbourhoods in the discourses of the 1940s, the demand for green surroundings was closely related to the need for physical activity, which had been a cause for concern since the late nineteenth century. Living close to nature was thought to be automatically stimulating, whereas traditional urban dwelling was considered to make people passive, or to drive them to less desirable

\footnotetext{
${ }^{39}$ J. Lahti, 'The Helsinki suburbs of Tapiola and Vantaanpuisto: post-war planning by the architect Aarne Ervi', Planning Perspectives, 23 (2008), 147-69; Clark and Hietala, 'Helsinki and green space, 1850-2000: an introduction', 183.

${ }^{40}$ Kaunis Koti, 8 (1967).

${ }^{41}$ Valtakunnansuunnittelu-Asuntopolitiikka, 4 (1967).
} 
activities such as going to the cinema or to cafés! ${ }^{42}$ Increasing interest in people's physical condition was connected with concerns about indecent behaviour and other moral issues. Health issues were increasingly being defined as social problems. Disease had earlier been viewed as a natural and mainly unavoidable phenomenon, but growth in scientific knowledge had framed it as a problem of the individual and the nation. The size and the health of the populace was seen as an important indicator of the strength of a nation. On the other hand, the project of public hygiene was undertaken to correct the negative effects of industrialization, urbanization and poor living conditions.

In the texts of garden city advocates, children would ideally play in their own backyards or in the nearby forest. If that was not possible, they would be offered playgrounds, sandboxes and apparatus such as climbing frames and swings. During the winter, children needed skating rinks and hills for sledging. Making use of the natural environment and good sports and hobby infrastructures would solve the problem of increasing free time and the lack of other appropriate activities. Indeed, the greater amount of available spare time was seen as a problem that needed to be solved.

Active work to promote playgrounds had begun in Helsinki at the beginning of the twentieth century. Teachers of physical education had submitted a proposal to the city council to develop its playgrounds. In addition to parks, they requested funding for playground leaders to supervise children's play in the afternoons. ${ }^{43}$ Playgrounds were seen as the solution to cramped housing, poor air quality and social isolation, especially for working-class children. At the same time, teachers had introduced summer camps and visits to farming families in the countryside for urban working-class children. The health and decency of children were a major concern of the different non-governmental organizations of the emerging citizen-state.

The network of sport grounds and parks with play areas was rather dense in the 1930s, but proper supervised playgrounds for children were mostly established from the 1950s onwards. The number of year-round playgrounds increased in Helsinki from 2 to 56 between 1951 and 1994, on top of smaller playgrounds and schoolyards freely open for the afternoons.

Because of the centralized organization and a tradition of strict regulations by the superintendents, the playgrounds remained as quite disciplined environments. Playground leaders had silver whistles carved with the city coat of arms, a manifest symbol of municipal power. Organized activities, such as games and singing, were preferred to free play. ${ }^{44}$ In 1957 , the playground officer of the city of Helsinki participated in a UN Europe playground seminar. Much of the discussion focused on 'Robinson playgrounds', where older children could be active and creative. According to contemporary experts, playgrounds should be more rudimentary, inspiring imagination and ingenuity and thereby cultivating children's spontaneity and self-esteem. ${ }^{45}$

\footnotetext{
${ }^{42}$ Von Herzen, Koti vaiko kasarmi lapsillemme, 7.

${ }^{43}$ P. Vilhunen, 80 Leikin Vuotta: Leikkipuistotoimintaa Helsingissä 1914-1994 (Helsinki, 1994), 2-3.

${ }^{44}$ Ibid., 9-10, 14.

${ }^{45}$ Lapsi ja nuoriso, 6-7 (1957).
} 
Robinson playgrounds provided material for making camp fires, building sheds or even digging tunnels on a model already established in Switzerland and Denmark. The Danish idea of 'junk playgrounds' was developed further in post-war Britain. Blighted or blitzed urban neighbourhoods provided a unique solution, for bombed-out empty lots contained genuine junk for children to play with. These adventure playgrounds would promote active citizenship and reconstruction through play. ${ }^{46}$ The Finnish delegation was reluctant to accept these kinds of ideas, for how could a sense of beauty be developed in children in this way? The need for more adventurous playgrounds was for the most part denied. First, there were still plenty of green spaces in Finnish cities, and in any case, city children were sent to the countryside during the summer 'where the best play areas actually existed'. ${ }^{47}$

Countless childhood memories describe the excitement of exploring wastelands, empty plots and sand pits. Such places were found everywhere in constantly transforming cities where construction, rebuilding and even restoration took place after the ravages of war. In one reminiscence, a wasteland area within the middle-class urban neighbourhood of Töölö was described as 'a world, as essential as the "grund" of school boys in Ference Molnár's Budapest'. ${ }^{48}$ As another writer from the same quarter portrayed his childhood as a 10-year-old boy in the 1940s: 'if there hadn't been a vacant lot nearby I have no idea where kids my age could have played'. There was a well-kept park in his area, but the swings were restricted to small children, it was closed at night and it had a park guard. ${ }^{49}$ The asphalted backyards provided some excitement along with the lively street life, but children were often not allowed to play there. This prohibition was enforced by the strict caretakers of the apartment buildings, often remembered by the fear they instilled in the children.

While the garden city advocates focused their critique on the dark asphalt quarters downtown, they forgot how green their city actually was. In addition to the designed parks, sports grounds and allotment gardens, there were plenty of wooded areas with rocks and boulders and the seashore at a short biking distance from anywhere in the city. ${ }^{50}$ Indeed, the city playground officer in 1957 was right - nature provided more than enough diversity to feed the imagination of children in the city itself. As they wrote at the time, the situation was not as drastic as in the slums of London. ${ }^{51}$ The extreme outbursts of post-war planning experts demanding green areas meant they were stuck in the old discourse of cramped industrial city slums, 'the filthy vaults of European cities' already feared in the nineteenth century. Although alarmism was, of course, an efficient rhetorical means to promote their causes.

\footnotetext{
${ }^{46}$ R. Kozlovsky, 'Adventure playgrounds and postwar reconstruction', in M. Gutman and N. de Coninck-Smith (eds.), Designing Modern Childhoods: History, Space, and the Material Culture of Children (New Brunswick, 2008), 175-81.

${ }^{47}$ Ibid.

${ }^{48} \mathrm{~K}$. Heiska, Töölö - kotikaupunginosamme: Töölö-seuran 25-vuotisjuhlajulkaisu (Helsinki, 1983), 53.

${ }^{49} \mathrm{~K}$. Heiska and H. Hongisto, Töölö: Kotikaupunginosamme. 2, Töölö-seura 1958-1988 (Helsinki, 1988), $50-1$.

${ }^{50}$ Laakkonen, 'Asphalt kids and the matrix city', 309.

${ }^{51}$ Lapsi ja nuoriso, 6-7 (1957).
} 


\section{The suburban reality of the 1960 s and 1970 s}

In the mid-1960s, a major paradigmatic change occurred in suburban planning ideals. The notion of forest suburbs close to nature was rejected. It was replaced by a compact city model, reintroducing the square shape block and street pattern, and emphasizing efficiency and the support of sociability. ${ }^{52}$ As a manifestation of this new paradigm, the new generation of architects organized two public events in 1966, Asuntopäivät (Housing Event) and Asuntonäyttely 66 (Housing Fair 66). The timing guaranteed wide attention; at the end of the same year, the National Housing Board was founded, and there were plans to build half a million new apartments during the next 10 years. ${ }^{53}$

The new generation's critique was directed at the principle of the scattered forests of garden suburbs and the spatial separation of different activities. The task of design, they argued, was not only to build decent apartments but also to create a socially functioning environment. This demand had been made before, but now it referred to quite the opposite from the 1940s and 1950s discourse. This time, a dense city structure which would guarantee a variety of services, leisure activities and contacts was required. The characteristics called for were diversity, vitality, stimuli and efficiency. ${ }^{54}$ To stimulate what was seen as the inadequate social life of the suburbs, these specialists relied on scientific planning of compact-type suburbs with space carefully created for diverse activities.

The western ideals of post-war urban planning, including the garden city and its Nordic versions - suburbs in the forest - were increasingly being questioned in the Finnish press from the 1960s on. ${ }^{55}$ The remote locations and poor public transport were criticized. The lack of infrastructure was also seen to have made suburban life monotonous, and the neighbourhoods were derided as being dull and lifeless. Suburbs were no longer even seen as ideal for children. There were no children's playground attendants as in the city centre, who would give mothers a chance to go downtown. According to the discourse, the lonely housewives felt abandoned and their small children suffered. The radical young architects of the 1966 exhibition had even questioned whether the peaceful surroundings of forest suburbs were suitable for children to grow up in. To them, it was the lively streets of the city centre that taught children to adapt to real society. Nor, they claimed, did children like the dull engineered playgrounds provided for them. ${ }^{56}$

The critique of suburbs as unattractive surroundings became stronger in the 1970s and the consequences for children were also at stake. Seppo Sauro argued in the report of the NGO Mannerheim League for Child Welfare in 1977 that children growing up in suburbs might be too separated from the rest of society. The television documentary 'Children in the suburbs' (1976) went even further, stating that it was a 'crime against children' to continue with the building patterns practised at the time. The documentary claimed that a childhood spent in a dull and

\footnotetext{
${ }^{52}$ J. Hankonen, Lähiöt ja tehokkuuden yhteiskunta (Tampere, 1994), 467.

${ }^{53}$ Ibid.

${ }^{54}$ Asuntonäyttely 66: Helsingin taidehallissa 29.10.-13.11.1966 (Helsinki, 1966).

${ }^{55}$ I. Roivainen, Sokeripala metsän keskellä. Lähiö sanomalehden konstruktiona (Helsinki, 1999).

${ }^{56}$ Asuntonäyttely 66, 32-3.
} 
lifeless environment could potentially cause insensitivity, violent eruptions and inability to perceive beauty and affection'. ${ }^{57}$

The critics were right in arguing that children need organic and not overly organized space for play and creativity. This was also well known by contemporary playground designers, who advocated places that inspired creative play. On the other hand, the denigrated forest suburbs were exactly what many children loved. Innumerable oral accounts and written reminiscences describe the sense of free play and adventure in the open spaces between the apartment buildings, and the vast areas around them.

\section{Urban experiences of children}

During the era of cramped housing, the outdoor environment played a major role in the lives of children. There was a lack of space indoors, and, furthermore, family time was scarce because of the long working hours of both parents. If mothers did not have paid work outside the home, their time was taken up in household chores. In addition, due to the rigorous health education, outdoor fresh air was considered to be imperative for children. Finnish babies still sleep outside even with temperatures below freezing.

As Laakkonen put it, children and the urban environment were connected by play. The pre-war downtown backyards might have been dull and plain, but a lot went on there. The labyrinths of cellars and attics, chasing rats and spying on locals provided excitement. Log piles provided adventure, and during the winter there were huge snowbanks to play on. On the other hand, various aspects of city life, including drunks and vagrants searching for shelter and scanning garbage bins, aroused fear. However, children's territories were not restricted to yards. Except for the youngest children, the diverse urban nature was close at hand and independently reachable. This was also true of various industrial zones that attracted the curious. ${ }^{58}$ Along similar lines, Heikki Paunonen, Jani Vuolteenaho and Terhi Ainiala noted that children's play in self-discovered areas in central Helsinki's working-class neighbourhood of Sörnäinen was often similar to the play of rural children. ${ }^{59}$

However, in the professional discourses from the 1940s to the early 1960s, the downtown urban environment was rarely considered suitable for children. Only one article noted that school-age boys actually liked to play in the labyrinthine backyards of the old city. ${ }^{60}$ This paradigm started to change only in the late 1960 s.

In several studies based on reminiscence, the ultimate enemies for children were adults. Caretakers and guards surveyed the yards and parks: '[he] chased away both girls and boys from the yard, no bouncing balls against the walls, no drawing hopscotch grids on the asphalt. You weren't even allowed to lean against the walls. ${ }^{61} \mathrm{In}$

\footnotetext{
${ }^{57}$ YLE, Lapset lähiössä (Children in the suburbs), 1976.

${ }^{58}$ Laakkonen, 'Asphalt kids and the matrix city'.

${ }^{59}$ Paunonen, Vuolteenaho and Ainiala, 'Industrial urbanization, working-class lads and slang toponyms in early twentieth-century Helsinki', 458-9.

${ }^{60}$ Kaunis Koti, 3 (1964).

${ }^{61}$ Olsson, 'Modes of living and local identity', 94. A reminiscence from the 1940s Kallio working-class quarters.
} 
the Siilitie district, the caretaker made young boys wash a garage door marked by a football. ${ }^{62}$ The right of any adult to give orders to any child was common at least until the 1970s. In an interview in 1972, a 10-year-old girl said she was pleased about playgrounds because everything was forbidden in her own yard. An 8-yearold boy wanted to get rid of the playground staff because adults were always nagging, and another girl, aged 10, continued that adults never allowed anything fun and considered everything to be dangerous. ${ }^{63}$

The new suburbs of the 1950s and 1960s particularly attracted families with children. The apartments were either sold with a special loan arrangement or were rented from the city. Dozens of accounts attest to the move from the very cramped and run-down one- to two-room residences downtown to bright and spacious new apartments with modern conveniences. Children enjoyed playing together in the large yards between apartment blocks. In addition, woods, rocks, cliffs and meadows opened up right behind the apartment buildings. As one female respondent recalled about the 1970s, the kids were wild and free and there were considerable opportunities for them to expend their energy. ${ }^{64}$ The forest suburbs promoted by the 1940s and 1950s experts and criticized in the 1960s were loved by the children themselves. They provided freedom for play and adventure away from adults' prying eyes.

The reverse side of this freedom was the danger and accidents. Minor bicycle accidents were common and major ones were long remembered. Risky play was more typical of boys, but girls too were interested in adventure. The rocks and cliffs around Helsinki attracted both boys and girls, offering exciting experiences of danger. This was also true of the industrial areas within the city, strictly forbidden to trespassers, with even more serious consequences. ${ }^{65}$ In a reminiscence from 1970 s Siilitie, a girl took part in searching for things in the garbage bins of an industrial plant. She described how they got there through a pipe tunnel, and mentioned how she enjoyed bicycling in the wide, quiet streets. ${ }^{66}$ In the suburbs as well as the central city, both the green and grey wastelands were explored by children. Traffic could cause harm anywhere, but the most warned about perils besides the traffic were child molesters.

During the 1970s, prominent public discourse related to the suburbs was problem-orientated. The suburbs were not only criticized for poor urban planning, they were also accused of having anti-social inhabitants. One aspect of the discourse was clashes between youth gangs. The children of the new suburbs had grown into rebellious youngsters, with nothing to do around their neighbourhood. This common negative view was challenged in the media of the 1990s by nostalgia for the suburbs. They had been wonderful surroundings for children to grow up in, plenty of playmates were at hand and nature was close by. ${ }^{67}$ Whatever the experts of the different decades had said, children preferred open and undesigned space to city streets.

\footnotetext{
${ }^{62}$ Kesänen, Siilitien tarinat, 44.

${ }^{63}$ Lapsi ja Nuoriso, 3 (1972).

${ }^{64}$ Astikainen, Heiskanen and Kaikkonen, Elämää lähiössä, 105.

${ }^{65}$ Laakkonen, 'Asphalt kids and the matrix city', 310, 312.

${ }^{66}$ Kesänen, Siilitien tarinat, 92.

${ }^{67}$ Astikainen, Heiskanen and Kaikkonen, Elämää lähiössä; Roivainen, Sokeripala metsän keskellä.
} 


\section{Discussion}

Rural children's idealized free play in the countryside was in fact often similar to the reality of urban children in post-war Helsinki. The old city was undoubtedly dirty, the quality of housing was poor, particularly in working-class neighbourhoods, and the traffic was increasingly dangerous, especially for the youngest. However, at the same time, the city was extremely green, with forest areas, the seaside, islands, beaches and rocks, providing interesting and diverse surroundings for many youngsters. As reminiscences reveal, the unplanned natural environment and wastelands had a particular importance for children. Young children often moved about by themselves and with their peers, but they also ran errands together with their parents and made trips to green areas with their families.

However, in the opinion of social reformists and some of the post-war planners, the traditional urban environment was not appropriate for children. The experiences and existing urban culture of children were ignored and even disparaged. In addition, the social reformists and other professionals in our sources rarely mentioned the existing infrastructure such as the playgrounds, sports fields and the sledging hills of downtown Helsinki. The discourse presented was black and white - or to be exact, black and green.

For families, housing built in pristine nature was the only acceptable option. The new garden cities were supposed to solve all urban problems. They promised to offer families space, nature, security and peace in the increasingly hectic urban conditions. A good housing environment in natural surroundings was thought to have a positive influence and to enhance family life.

In the 1960s and 1970s, many Finnish children's rural or downtown urban living environments were replaced by suburban yards and green spaces. The generations raised in the newly built suburbs also recall their neighbourhood environment with nostalgia. Nature was everywhere, there were plenty of families, and friends to play with. The children could move about relatively safely since cars were often separated from pedestrians.

Towards the end of the 1960s, the baby boomer generation was growing up and criticism of the suburbs increased. Newly built suburbs were criticized for their lack of services such as poor public transport and for being too family-oriented. There were even claims that the suburbs were no longer ideal for children. It was suggested that families would not necessarily need their own neighbourhoods; instead, children were supposed to acquire an urban lifestyle and enjoy the urban amenities.

Despite the criticism, suburban living prevailed as an ideal for families for a long time. The emphasis on the superiority of the suburbs for family life also meant that there was very little interest in developing a safer, more child-friendly downtown area. As Lia Karsten has noted, family-orientated suburbanization led to less public attention being focused on children in the central cities. ${ }^{68}$ Johanna Lilius too has pointed out that modernist ideals concerning urban family living have meant that downtown areas have not been considered ideal for families to this day. ${ }^{69}$

\footnotetext{
${ }^{68}$ L. Karsten, 'Historical traces: the changing boundaries between children's private and public urban spaces over the last century', in K. Vesikansa (ed.), Mixing the Private and the Public in the City (Espoo, 2018), p. 101, aaltodoc.aalto.fi/bitstream/handle/123456789/37052/isbn9789526083476.pdf? sequence=1\&isAllowed=y.

${ }^{69}$ Lilius, 'Is there room for families in the inner city?', 843.
} 
Thus, the legacy the post-war reformists left for future generations - both city planners and ordinary people - was the strong conviction that only suburban environments were ideal for children. These attitudes have only recently begun to change.

How did the discussions and development of Helsinki contribute to the culture of children's independent mobility? In 1940s and 1950s Helsinki, children moved around quite independently. This was due to the small amount of motorized traffic, the stimulating country-like urban environment combined with children's natural curiosity, a common sense of trust and a lack of adult supervision. Children were expected to be self-reliant and independent. ${ }^{70}$

However, accidents were common and in the social reformists' and planners' professional discourses analysed here, this ethos had come to an end. ${ }^{71}$ The general consensus was that children had to be protected from increasing traffic and they needed safe places to play. Lia Karsten states that a major change occurred in the Netherlands in children's use of space between 1975 and 1995 when 'the discourse on children changed from resilient to vulnerable. ${ }^{72}$ Similar changes are evident from the texts of the social reformists, architects, journalists and child specialists of the 1940s to the 1960s and 1970s, reviewed for this article.

The demands by these professionals also changed the urban structure. The number of supervised year-round playgrounds continued to multiply in Helsinki and the requirement for play areas near residential housing expanded. In the new suburbs, motorized traffic was separated from pedestrians, and playgrounds for the youngest children were located in the immediate vicinity of homes so that parents could supervise them from their living room and kitchen windows. ${ }^{73}$

At the same time, children's use of outdoor space was diminishing with the emerging attraction of indoor activities. On average, families had more space inside their homes than before and children could spend more time indoors. Radios were already common, but a major change was the breakthrough of television in the 1960s. There were fewer than 100,000 television licences at the beginning of the 1960s, but over a million by the end of the decade, and the numbers kept growing. Furthermore, the number of special programmes for children and teenagers increased.

Although the post-war professionals clearly intended to limit children's right to roam freely in order to keep children safe, the demands and execution of suburban planning also supported children's independent mobility. In the new suburbs, children, although increasingly guided, would still move around actively by themselves and with their peers. Small children could play among themselves because they could be supervised intermittently by their parents from their windows at home. Children could also go to school safely and play games by themselves as sidewalks were separated from motorized traffic. Playgrounds, sports fields and abundant green areas offered children play spaces in the vicinity of their homes so that

\footnotetext{
${ }^{70}$ S. Näre and J. Kirves, 'Lapsuus sodan keskellä', in M. Turtola (ed.), Kotirintama (Helsinki, 2018), 250, 255.

${ }^{71}$ About accidents, see, e.g., A. Malinen and T. Tamminen, Jälleenrakentajien lapset: Sotienjälkeinen Suomi lapsen silmin (Helsinki, 2017), 280.

${ }^{72}$ Karsten, 'Historical traces', 101.

${ }^{73}$ Saarikangas, 'Sandboxes and heavenly dwellings', 49.
} 
parents did not necessarily have to accompany their children to their recreational activities.

Other important factors contributing to children's opportunities to move around by themselves or with their peers in post-war downtown Helsinki and suburbs were the increasingly dense school network and a relatively well-functioning public transport system. Moreover, where both parents worked, there was limited scope to look after their children, thus limiting the possibilities of supervision. Parents have appreciated children's independent mobility and have been willing to teach their children how to move around by themselves. Also, the inter-personal trust associated with the inhabitants of Nordic countries has been offered as an explanation for children's independent mobility. ${ }^{74}$

In fact, it could be argued that the long-standing overall discourses about the importance of outdoor play and physical exercise for children, the necessity of fresh air, light and sunshine for their health and the benefits of green surroundings have led to the appreciation of independent mobility and outdoor activities, instead of the over-protection of children.

\footnotetext{
${ }^{74} \mathrm{~V}$. Moll and L. Nevalainen, "Silloin oli ihan normaalia, että lapset kulkivat tarhaan ja sieltä kotiin." Muistitietoaineistojen itsenäiset kaupunkilaislapset', Elore, 25 (2018), 49; K. Kullman, 'Transitional geographies: making mobile children', Social and Cultural Geography, 11 (2010), 831; M. Kyttä, J. Hirvonen, J. Rudner, I. Pirjola and T. Laatikainen, 'The last free-range children? Children's independent mobility in Finland in the 1990s and 2010s', Journal of Transport Geography, 47 (2015), 8-9.
}

Cite this article: Moll V, Kuusi H (2021). From city streets to suburban woodlands: the urban planning debate on children's needs, and childhood reminiscences, of 1940s-1970s Helsinki. Urban History 48, 125-142. https://doi.org/10.1017/S096392681900083X 